\title{
Analysis of Factors Affecting Employee Performance at Aetra Regional Drinking Water Company of Jakarta (PDAM)
}

\author{
Yunita Fajar Sari ${ }^{1}$, Rukun Santoso ${ }^{2}$, Erwin Permana ${ }^{3}$, Wiwin $^{4}$, Ratih Ayu $\mathrm{S}^{5}$ \\ ${ }^{1245}$ Universitas Islam Jakarta, Indonesia \\ ${ }^{3}$ Universitas Pancasila, Indonesia \\ Correspondent: yunithafs20@gmail.com ${ }^{1}$, rukunsantoso1859@gmail.com² \\ Erwin.permana@univpancasila.ac.id ${ }^{3}$,wiwin@uid.ac.id ${ }^{4}$, ratihayus13@gmail.com $^{5}$
}

$\begin{array}{ll}\text { Received } & \text { : August 5, } 2021 \\ \text { Accepted } & \text { : January 15, } 2022 \\ \text { Published } & \text { : January 31, } 2022\end{array}$

Citation: Sari, Y.F., Santoso, R., Permana, E., Wiwin., \& Sekarini, R., A. (2022). Analysis of Factors Affecting Employee Performance at Aetra Regional Drinking Water Company of Jakarta (PDAM). Ilomata International Journal of Management, 3(1), 104-119. https://doi.org/10.52728/ijim.v3i1.407

\begin{abstract}
The research at Aetra Air Drinking Water Regional Company of East Jakarta (PDAM) aims to analyze: 1) the influence of work discipline on employee performance, 2) The Effect of Occupational Safety and Health (K3) on employee performance. 3) The simultaneous influence of work discipline and Occupational Safety and Health (K3) on employee performance. The research approach used quantitative paradigms. The population was 339 people and the determination of samples used the Slovin technique so that a sample of 77 respondents was obtained. Data analysis used a co-existing linear regression test by using SPSS. The results show that Work Discipline and Occupational Safety and Health (K3), both simultaneously and significantly affect the performance of employees of PT. AETRA AIR Jakarta, while the managerial implication of these findings is the need for efforts to improve the employee performance of PT. AETRA AIR Jakarta. Referring to the findings of this study, among others, there is a need for firmness from the agency about the employees' problems, especially for those whose absence rate is high enough to improve discipline. The reason is that the problem of indiscipline affects other employees so that it will affect the overall performance of the company. This research shows that matters related to discipline, and Occupational Safety and Health (K3) should be more considered and always improved to further boost the employee performance at PT Aetra Air Jakarta. Discipline should be improved in terms of supervision from HRD while Occupational Safety and Health (K3) involves other parties/agencies in terms of the Occupational Safety and Health (K3) management system.
\end{abstract}

Keywords: Work Discipline, Occupational Safety and Health (K3), and Performance 


\section{INTRODUCTION}

In every organization, both public and business organizations Human Resources are the main resources of the organization (Permana et al., 2020; Tordera et al., 2020). Accordingly, humans become the main actors who will drive various other organizational resources. Then, every

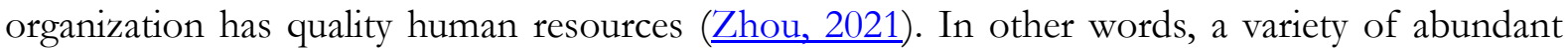
resources if not handled by HR competencies will be useless because they cannot be managed and utilized properly ( Kazakovs et al., 2015). For this reason, the organization is required to plan and develop the quality of human resources continuously (Cai et al., 2018; Purbaningrat, 2012)

One company that has paid attention to Human Resources so that employee performance improves is Aetra Air Drinking Water Regional Company of Jakarta (PDAM). Based on personnel data in 2020, it is found that the discipline of employees at Aetra Air Drinking Water Regional Company of Jakarta (PDAM) is still very low. It is known from the presence of some employees who have stolen time during working hours, although fingerprint time attendance is used to make employees unable to represent their absence to others. However, some have stolen time in which they come to the office in the morning to be absent and do other activities outside that have nothing to do with the job, then they come back in the afternoon to fill in their attendance. In addition, there are still many employees who come late to the office (not on time).

Table 1.

Absence of employees in all activities of Aetra Air Drinking Water Regional Company of Jakarta (PDAM)

\begin{tabular}{llcccc}
\hline No & \multicolumn{1}{c}{ Description } & $\begin{array}{c}\text { Number of } \\
\text { Employees } \\
\text { (persons) }\end{array}$ & $\begin{array}{c}\text { Number of Employees } \\
\text { who are absent for } \\
\text { several reasons (persons) }\end{array}$ & $\begin{array}{c}\text { \% of } \\
\text { Absence }\end{array}$ & $\begin{array}{c}\text { Absence }> \\
\text { 10 days } \\
\text { (persons) }\end{array}$ \\
\hline $\mathbf{1}$ & Sick & 339 & 134 & 39.53 & 9 \\
\hline $\mathbf{2}$ & Permission & 339 & 174 & 51.33 & \\
\hline $\mathbf{3}$ & Absent & 339 & 55 & 16.22 & \\
\hline $\mathbf{4}$ & $\begin{array}{l}\text { Not participating } \\
\text { in flag raising } \\
\text { ceremony }\end{array}$ & 339 & 137 & 40.41 & \\
\hline $\mathbf{5}$ & $\begin{array}{l}\text { Not participating } \\
\text { in }\end{array}$ & 339 & 190 & 56.05 & \\
& $\begin{array}{l}\text { Gymnastics/Qura } \\
\text { n Recitation }\end{array}$ & & & & \\
\hline $\mathbf{6}$ & $\begin{array}{l}\text { Leave } \\
\text { Dispensation }\end{array}$ & 339 & 42 & 12.39 & \\
\hline
\end{tabular}

Source: Personnel Section of PDAM Aetra Jakarta (2020)

From the table above, it is apparent that the percentage of the absence of employees was quite high in all activities at the Aetra Regional Drinking Water Company of Jakarta (PDAM) during 2019. Having permissions and not participating in gymnastics/Quran recitation activities had a percentage above $50 \%$ of total employees. The low level of employee attendance will affect the 


\section{Analysis of Factors Affecting Employee Performance at Aetra Regional Drinking Water Company of Jakarta (PDAM) \\ Sari, Santoso, Permana, Wiwin., Sekarini}

achievement of the tasks assigned by the leaders. The tasks given by the leaders will not be completed properly, and there are shortcomings because the employees are negligent and do not make the most of their time to do the tasks. This kind of attitude is also very harmful to Aetra Regional Water Company of Jakarta (PDAM) because the existing activities do not run properly due to unfinished tasks and inadequate employee attendance.

In addition to discipline, another factor that affects the performance of employees at Aetra Regional Water Company of Jakarta (PDAM) is that it still does not have an Occupational Safety and Health Management System (SMK3) although the Company has owned Occupational Safety and Health (K3) equipment. K3 is very important to create an occupational safety and health system in the workplace by involving elements of management, labor, working conditions, and an integrated environment to prevent and reduce occupational accidents and diseases job, as well as to create a safe, comfortable, efficient and effective and productive workplace (Hebbie, 2020). Based on research carried out in the United States, the job of an employee at PDAM is classified as having high risks of health problems (Carden et al., 2021; Wangi, 2020).

By taking into account the above explanation, it is necessary to conduct specific research that examines whether the factors of work discipline and Occupational Safety and Health (K3) affect the performance of employees at Aetra Air Regional Water Company of Jakarta (PDAM) Jakarta. This research is important to produce managerial recommendations for the company to improve employee performance, considering that PDAM is one of the companies that fulfill the needs of many people.

Management is the process of planning, organizing, directing, and supervising the efforts of the members and the use of other organizational resources to achieve the stated goals (Utamy et al., 2020). Human Resource Management (HRM) is defined as the management and utilization of resources that exist in an individual. Furthermore, it is argued that HRM is a process to acquire, train, assess, and compensate employees and manage labor relations, health and safety, and matters relating to justice (Asadullah et al., 2021; Pujangkoro, 2011).

Activities in the field of HRD can be understood from two perspectives, namely from the sides of job and employees. From the side of the job, it consists of job analysis and evaluation. Meanwhile, in terms of employees, it includes activities for manpower procurement, job performance appraisal, training and development, promotion, compensation, and termination of employment. The achievement of these activities can be carried out through a performance appraisal (Avery et al., 2015; Khtatbeh et al., 2020).

Performance is the result of a job that can be achieved by a person or group of people in a company following their respective authorities and responsibilities to achieve organizational goals legally, not violating the law, and not contrary to morals and ethics (Peong, 2019; Zhang, 2018).

Employee performance is defined as an employee's ability to perform certain skills. Employee performance is indispensable because with this performance it will be known how far their abilities are in carrying out the tasks assigned to them (Ningsih et al., 2021; Rustandi, 2019). For this reason, it is necessary to determine clear and measurable criteria which are set together to serve as a reference. In a corporate organization, the aspects of capable, skilled, and 


\section{Analysis of Factors Affecting Employee Performance at Aetra Regional Drinking Water Company of Jakarta (PDAM) \\ Sari, Santoso, Permana, Wiwin., Sekarini}

responsible employees are the assets of the company which are very valuable for the survival of the company (Fahmi, 2016; Piwowar-Sulej, 2021).

Factors that can affect employee performance may include abilities and expertise, knowledge, work design, personality, work motivation, leadership, leadership style, organizational culture, job satisfaction, work environment, loyalty, commitment, and work discipline (Adrizayani, 2014; Kummetha et al., 2020). Of the various factors that affect employee performance described above, this research only discusses work discipline and work environment which are narrowed in scope through occupational safety and health (Adzim, 2021; Lafuente \& Abad, 2021; Rahman, 2020).

Discipline is the willingness of someone which arises with his awareness to follow the applied rules in the organization (Handoko, 2013; Wicaksono, 2016). Discipline is the attitude of individuals and groups that guarantees compliance with "orders" and takes the initiative to take the necessary actions if there are no "orders" (Diana, 2015). Meanwhile, the discipline of implementing management is to strengthen and implement organizational guidelines. Based on the three concepts above, it can be concluded that discipline is obedience to the rules or orders set by the organization ( Handoko, 2013; Lussy, 2018).

In addition to work discipline, the variables that are suspected to influence the performance of the employees of Jakarta Aetra Air (PDAM) are Occupational Safety and Health (K3). Occupational Safety and Health (K3) is a thought and effort to ensure the integrity and perfection of both physical and spiritual labor in particular, and humans in general and the results of work and culture towards a just and prosperous society (Rahman, 2020; Zahara, 2018).

K3 refers to the physiological, physical, and psychological conditions of the workforce caused by the work environment provided by the organization. Physiological and physical conditions include diseases and work accidents that result in death or loss of limbs, injuries caused by repetitive movements, back pain, syndrome of various types of cancer, and various other dangerous diseases (Ardika et al., 2015; Mahawati et al., 2021). The variables of Work Discipline and Occupational Safety and Health (K3) are predicted to affect the performance of employees at Aetra Air Jakarta (PDAM). Good employee performance will result in the most favorable company performance as well.

Performance is the result of work in quality and quantity achieved by an employee to carry out his duties following the responsibilities given to him (Herlinawati \& Zulfikar, 2020; Irmawan, 2020). Performance is a result of work achieved by someone to carry out the tasks assigned to him based on his skills, experience, and sincerity as well as time (Rustandi, 2019). In most organizations, the performance of individual employees determines the success of the organization/company.

Performance is divided into two, namely individual performance and organizational performance (Edison et al., 2017; McLarty et al., 2021). Individual performance is the result of the work of the employees both in terms of quality and quantity based on predetermined work standards, while organizational performance is a combination of individual performance and group performance (Bisht \& Mahajan, 2021; Mahawati et al., 2021). Based on some of the above definitions, it can be concluded that performance is the result of work that can be achieved by someone to complete the tasks assigned to him based on his skills, experience, sincerity, and time. In assess 


\section{Analysis of Factors Affecting Employee Performance at Aetra Regional Drinking Water Company of Jakarta (PDAM) \\ Sari, Santoso, Permana, Wiwin., Sekarini}

the performance of an employee, various aspects of the assessment are needed including knowledge of work, leadership initiative, quality of work, cooperation, decision making, creativity, reliability, planning, communication, intelligence, problem-solving, delegation, attitude, motivational effort, and organization (Ogunmokun et al., 2020; Permana et al., 2019). Based on this explanation, this study proposes three research hypotheses, namely:

H1 = Work discipline affects performance

$\mathrm{H} 2$ = Occupational Safety and Health (K3) affects performance

H3 = Work discipline and (K3) simultaneously affect performance

\section{METHOD}

The population in this study were all employees of Aetra Air Jakarta (PDAM). Samples were taken randomly from all parts of Aetra Air Jakarta (PDAM). The population of employees working at Aetra Air Jakarta (PDAM). consisting of undergraduate, high school, junior high, and elementary school graduates with a total of 339 employees. Based on the population, a sampling process was carried out using the Slovin formula and the number of respondents totalling 77 people was obtained consisting of all levels, from leadership to staff. There was a concern about the level of educational background, length of work, and gender. The sampling technique was done by Simple Random Sampling so that the population had the same opportunity to provide the required data (Creswell, 2017; Sugiyono, 2019).

The technique of collecting samples was done by interviews. Through interviews, actual information was obtained regarding the organizational structure, school facilities, and other data so that it can complete this research. The questionnaire items were derived from research variables, namely work discipline, occupational safety, and health as well as performance. The following is a table of research instruments:

Table 1. Research Instruments

\begin{tabular}{|c|c|c|c|c|}
\hline No & Variables & Dimensions & Indicators & Items \\
\hline & \multirow[t]{7}{*}{$\begin{array}{l}\text { Work discipline } \\
\text { (X1) }\end{array}$} & 1. Goals and Abilities & $\begin{array}{l}\text { 1. Job according to educational } \\
\text { background }\end{array}$ & 1 \\
\hline & & 2. Exemplary Leaders & $\begin{array}{l}\text { 2. Leaders who arrive on time and } \\
\text { enforce the rules }\end{array}$ & 2 \\
\hline & & 3. Kickback & 3. Guaranteed welfare & 3 \\
\hline & & 4. Justice & 4. The agency is fair to all employees & 4 \\
\hline & & 5. Inherent Control & 5. Leaders exercise inherent control & 5 \\
\hline & & 6. Firmness & $\begin{array}{l}\text { 6. Deterrent effects for employees who } \\
\text { violate the rules. }\end{array}$ & 6 \\
\hline & & 7. Legal sanctions & $\begin{array}{l}\text { 7. The agency takes firm action against } \\
\text { disciplinary employees }\end{array}$ & 7 \\
\hline
\end{tabular}


Analysis of Factors Affecting Employee Performance at Aetra Regional Drinking Water Company of Jakarta (PDAM)

Sari, Santoso, Permana, Wiwin., Sekarini

\begin{tabular}{|c|c|c|c|c|}
\hline & & 8. Human Relations & 8. Be happy if other employees succeed & 8 \\
\hline \multirow[t]{5}{*}{2} & \multirow{5}{*}{$\begin{array}{l}\text { Occupational } \\
\text { Safety and } \\
\text { Health (X2) }\end{array}$} & 1. Safe storage of goods & $\begin{array}{l}\text { 1. Dangerous goods/equipment must } \\
\text { be marked }\end{array}$ & 9 \\
\hline & & 2. Comfortable workspace & 2. Clean and pollution-free workspace & 10 \\
\hline & & 3. Waste disposal available & 3. Provide a waste treatment area & 11 \\
\hline & & 4. Safe work equipment & 4. Provide work tools and equipment & 12 \\
\hline & & $\begin{array}{l}\text { 5. Good electronic } \\
\text { machinery and } \\
\text { equipment with lighting } \\
\text { settings }\end{array}$ & $\begin{array}{l}\text { 5. Machinery and other electronic } \\
\text { equipment are well maintained with } \\
\text { lighting }\end{array}$ & 13 \\
\hline \multirow[t]{7}{*}{3} & \multirow{7}{*}{$\begin{array}{l}\text { Employee } \\
\text { Performance } \\
\text { (Y) }\end{array}$} & 1. Loyalty & 1. Loyal to work & 14 \\
\hline & & 2. Work performance & 2. Have achievements to be proud of & 15 \\
\hline & & 3. Discipline & 3. Work on time & 16 \\
\hline & & 4. Creativity & $\begin{array}{l}\text { 4. Have creative ideas in completing } \\
\text { work }\end{array}$ & 17 \\
\hline & & 5. Cooperation & 5. Able to work with other people & 18 \\
\hline & & 6. Skills & 6. Able to finish the job well & 19 \\
\hline & & 7. Responsibility & 7. Responsibility for completing work & 20 \\
\hline
\end{tabular}

Data analysis used multiple linear analyses. According to Sugiyono, (2016) multiple linear regression analysis is an analytical tool that can be used to determine the influence between the independent and the dependent variables, namely between work discipline (X1), occupational safety, and health (X2), and employee performance (Y). Partial Significance Test (Test Statistical of $\mathrm{t}$ ). The t-test was conducted to examine the effect of the independent variables (work discipline and occupational safety and health) partially on the dependent variable (employee performance). Simultaneous Significance Test (Statistical Test F). The F test is used to test the effect of the independent variables together against the dependent variable. According to Ghozali (2011), if the value of Sig. $<0,05$, it means that the independent variable (X) simultaneously affects the dependent variable (Y). Determination Analysis in multiple linear regression is used to determine the percentage contribution of the influence of the independent variables at the same time (simultaneously) on the dependent variable. The coefficient of simultaneous determination (R2) is used to determine the magnitude of the effect of work discipline and $\mathrm{K} 3$ on employee performance from the research results. If the R2 obtained is close to 1 , it can be said that the model is stronger in explaining the variation of the independent variable to the dependent variable; on the contrary, if R2 is close to zero, the variation of the independent variable is weaker in explaining the attached variable. 


\section{RESULT AND DISCUSSION}

The research instrument is said to have validity if the instrument can be used to measure symptoms according to what is defined (Ghozali, 2016; Sugiyono, 2019). The measurement of indicators of the three research variables was carried out through a questionnaire consisting of a list of closed statements and distributed to respondents with an ordinal measurement scale and five answer options provided, namely Strongly Agree (SS); Agree (S); Neutral/ Indecisive (R); Disagree (TS), and Strongly Disagree (STS). In this validity and reliability test, the researcher conducted an analysis using SPSS version 22 . The validity test was obtained based on the SPSS output formulation as follows:

Table 2. Validity Test

Case Processing Summary

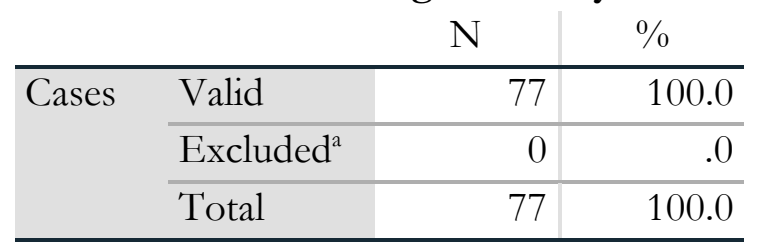

a. Listwise deletion based on all variables in the procedure.

Source: SPSS Output, 2020.

Based on the SPSS output, it is evident that as many as 77 respondents gave valid answers. Next, the reliability of the research construct is shown, the results of the reliability test obtained are as follows:

Table 3. Reliability Test Results of Data Collection Tools Per Question

\begin{tabular}{|c|c|}
\hline \multicolumn{2}{|c|}{ Reliability Statistics } \\
\hline Cronbach's & \\
\hline Alpha & $\mathrm{N}$ of Items \\
\hline .967 & 77 \\
\hline
\end{tabular}

From the table above, it is known that all question items have a reliability value of 0.967 , so it can be said that these data have very good reliability (Ghozali, 2011).

Table. 4

Descriptive Statistics Test Results

\begin{tabular}{lrrrrr}
\hline \multicolumn{7}{c}{ Descriptive Statistics } \\
\hline Work Discipline & 77 & Minimum & Maximum & Mean & Std. Deviation \\
\hline K3 & 77 & 12 & 40 & 37,45 & 3,331 \\
\hline Employee & 77 & 24 & 35 & 32,34 & 2,976 \\
Performance & & & & & \\
\hline Valid N (listwise) & 77 & & & & \\
\hline
\end{tabular}

Source: Research Data Processing Results (2020) 


\section{Analysis of Factors Affecting Employee Performance at Aetra Regional Drinking Water Company of Jakarta (PDAM) \\ Sari, Santoso, Permana, Wiwin., Sekarini}

Based on the results of the descriptive statistical test above, it can be seen that the number of respondents is 77 people, the lowest work discipline variable value is 27 and the highest work discipline value is 40 , with an average discipline value of 77 respondents is 37,45 with a standard deviation of 3, 33. Furthermore, the lowest value of the Occupational Safety and Health (K3) variable is 12 and the highest Occupational Safety and Health (K3) variable value is 25, with an average $\mathrm{K} 3$ value of 77 respondents is 22,90 with a standard deviation of 2,98. Meanwhile, when viewed from the value of the employee performance variable, the lowest is 24 and the highest employee performance value is 35 , with the average performance value of 77 respondents is 32.34 with a standard deviation of 2,58.

\section{HYPOTHESIS TESTING}

This t-statistical test aims to show how much influence the individual independent variables have in explaining the variation of the dependent variable tested at a significance level of 0.05 (Ghozali, 2006). The decision making is by comparing the $t$ count with the $t$ table with the criteria as stated (Ghozali, 2011), as follows:

$$
\begin{aligned}
& \text { If } t \text { count }>\mathrm{t} \text { table }=\mathrm{H}_{0} \text { rejected } \\
& \text { If } t \text { count }<\mathrm{t} \text { table }=\mathrm{H}_{0} \text { accepted }
\end{aligned}
$$

Based on the decision making described above, the results of the significance test (t-test statistic) will be able to know the magnitude of the influence of each independent variable on the dependent variable. The first hypothesis states the magnitude of the effect of work discipline on employee performance at PDAM Aetra Air Jakarta, which is measured by the dimensions of work discipline. The results of the significance test (Test Statistical of T) were calculated by SPSS, the results can be seen in the following table:

\begin{tabular}{|c|c|c|c|c|c|c|c|c|}
\hline \multicolumn{9}{|c|}{ Coefficients } \\
\hline \multirow{2}{*}{\multicolumn{2}{|c|}{ Model }} & \multicolumn{2}{|c|}{$\begin{array}{l}\text { Unstandardized } \\
\text { Coefficients }\end{array}$} & \multirow{2}{*}{$\begin{array}{c}\text { Standardized } \\
\text { Coefficients } \\
\text { Beta }\end{array}$} & \multirow[t]{2}{*}{$\mathrm{t}$} & \multirow[t]{2}{*}{ Sig. } & \multicolumn{2}{|c|}{ Collinearity Statistics } \\
\hline & & B & $\begin{array}{l}\text { Std. } \\
\text { Error }\end{array}$ & & & & Tolerance & VIF \\
\hline 1 & (Constant) & 16,349 & 2,797 & & $\begin{array}{r}5,84 \\
5\end{array}$ &, 000 & & \\
\hline & $\begin{array}{l}\text { Work } \\
\text { Discipline }\end{array}$ & 234 & 086 & 303 & $\begin{array}{r}2,72 \\
7\end{array}$ & ,008 &, 724 & 1,381 \\
\hline & K3 & 315 & ,096 & 363 & $\begin{array}{r}3,27 \\
4\end{array}$ &, 002 & ,724 & 1,381 \\
\hline
\end{tabular}

Table 4. Results of Partial Significance Test (T-Test Statistics)

a. Dependent Variable: Employee Performance

Source: Data Processing Results (2020)

To test the first hypothesis, it can be seen in the calculation in table 4 , which shows the work discipline variable has a significance of 0,008 which means it is smaller than $0,05(0,008<0,05)$, and the $t$ value is $2,727>\mathrm{t}$ table 1,992 . it is concluded that the hypothesis (H1) is proven. In other words, work discipline affects employee performance at PDAM Aetra Air Jakarta. 
While the second hypothesis is based on the calculations in table 4, it can be seen that the Occupational Safety and Health (K3) variable has a significance of 0,002 which means it is smaller than $0.05(0,002<0,05)$, and $t_{\text {count }}$ value is $3,274>t_{\text {table }} 1,992$. So, it can be concluded that it is proven that $\mathrm{K} 3$ influences employee performance at PT Aetra Air Jakarta.

A simultaneous effect test is carried out by conducting the $\mathrm{F}$ test. Simultaneous hypothesis testing aims to measure the magnitude of the independent influence together on the dependent variable.

Table 5.

Simultaneous Significance Test Results (F Statistical Test)

\begin{tabular}{|c|c|c|c|c|c|c|}
\hline \multicolumn{7}{|c|}{ ANOVA } \\
\hline Model & & Sum of & $\mathrm{Df}$ & Mean & F & Sig. \\
\hline \multirow[t]{3}{*}{1} & $\begin{array}{l}\text { Regressio } \\
\mathrm{n}\end{array}$ & 171,459 & 2 & 85,729 & 19,007 &, $000^{\mathrm{b}}$ \\
\hline & Residual & 333,762 & 74 & 4,510 & & \\
\hline & Total & 505,221 & 76 & & & \\
\hline
\end{tabular}

\begin{tabular}{l}
\hline a. Dependent Variable: Employee Performance \\
\hline b. Predictors: (Constant), K3, Work Discipline \\
\hline
\end{tabular}

Source: Data Processing Results (2020)

Based on the statistical calculation of $\mathrm{F}$ as shown in table 5 , a significance of $0,000 \mathrm{~b}$ is obtained. By using a significance level of 0,05 , the $\mathrm{F}$ significance value of 0,000 indicates that it is smaller than $0,05(0,000<0,05)$ and the $F_{\text {count }} 19.007>F_{\text {table }} 3,12$. Thus $\mathrm{Ha}$ is accepted, so the hypothesis which states the magnitude of the effect of work discipline and occupational safety and health (K3) together on employee performance at PT Aetra Air Jakarta, can be accepted.

Furthermore, the Coefficient of determination test aims to determine how much the ability of the independent variable to explain the dependent variable. The results of the coefficient of determination using SPSS can be seen in the following table:

Table 6.

Results of Coefficient of Determination Test $\left(\mathbf{R}_{2}\right)$

\begin{tabular}{|c|c|c|c|c|c|}
\hline \multicolumn{6}{|c|}{ Model Summaryb } \\
\hline $\begin{array}{l}\text { Mod } \\
\text { el }\end{array}$ & $\mathrm{R}$ & $\begin{array}{c}\mathrm{R} \\
\text { Square }\end{array}$ & $\begin{array}{l}\text { Adjusted R } \\
\text { Square }\end{array}$ & $\begin{array}{l}\text { Std. Error of } \\
\text { the Estimate }\end{array}$ & $\begin{array}{l}\text { Durbin- } \\
\text { Watson }\end{array}$ \\
\hline 1 &, $583^{\mathrm{a}}$ & ,339 & ,322 & 2,124 & 1,558 \\
\hline \multicolumn{6}{|c|}{ a. Predictors: (Constant), K3, Work Discipline } \\
\hline \multicolumn{6}{|c|}{ b. Dependent Variable: Employee Performance } \\
\hline
\end{tabular}

Based on table 6 , the $\mathrm{R}$ Square number is 0,339 . So, it can be concluded that $33,9 \%$ is a factor that affects the dependent variable (employee performance) which is explained by the independent variable (work discipline and K3). While the rest $(100 \%-33.9 \%=66,1 \%)$ is explained by other variables that are not included in this study. 


\section{Analysis of Factors Affecting Employee Performance at Aetra Regional Drinking Water Company of Jakarta (PDAM) \\ Sari, Santoso, Permana, Wiwin., Sekarini}

From the hypothesis test, it was found that there is a positive influence between work discipline (X1) on employee performance (Y). For employees, discipline is one of the keys to success in completing their duties and obligations (Hardiyanti, 2017). On the other hand, the organization will also benefit from implementing a disciplinary policy. Without discipline and the threat of disciplinary action, the effectiveness of the organization will be very limited (Lan et al., 2021). The results of this study are reinforced by the previous findings, which states that discipline has a strong influence on performance (Hardiyanti, 2017). This result is supported by another research which state that work discipline is needed by employees to achieve agency success (Arifudin et al., 2017). With discipline, an employee can find out the mistakes he has violated so that he will improve himself and comply with the regulations set by the agency (Maden-Eyiusta \& Alten, 2021). The higher the level of employee work discipline, the higher the resulting performance of the employee (Sujatha \& Krishnaveni, 2018).

Related to agencies or organizations within PT Aetra Air Jakarta, it is expected that they can further enforce employee discipline because it is realized that discipline is the key that drives employee performance as a whole. Discipline is one of the starting points of success in achieving the goals of an organization. The discipline itself aims to make all employees in the company willing to voluntarily without feeling compelled to obey or comply with the rules that have been determined by the company.

Related to the second hypothesis, namely the positive influence between occupational safety and health (X2). The positive t-count value means that the effect that occurs is positive, it can be interpreted that the higher or better the occupational safety and health, the higher the employee's performance. These findings are following the results of previous research that occupational safety and health also affect employee performance (Wangi, 2020). Salvation is a thought and effort to ensure the wholeness and perfection of both physical and spiritual. The company implements work safety to create a conducive environment and aims to support the performance improvement process. The human factor is a determinant of the success of the implementation of the vision, mission, and in achieving the company's targets. The main purpose of work safety is for employees in an institution to get optimal health so that they can achieve high work productivity (Utamy et al., 2020).

Work safety is a condition in which workers feel safe and comfortable, with treatment obtained from the environment and affects the quality of work. Feelings of comfort start from within the workforce, either they are comfortable with the equipment, occupational health, equipment used, or workspace layout and workload obtained at work. Performance measures for a factory manager can be seen from several items, one of which is about employee safety or how many accidents are committed by employees (Agha et al., 2011). It can be concluded that work safety is one of the important factors and has an influence on employee performance (Erpurini, 2019). Occupational safety and health protect workers/laborers to achieve optimal performance (Alfalla-Luque et al., 2015). With the implementation of occupational safety and health effects, workers will feel safe and comfortable in the work environment, so that employees can work more focused without feeling pressured by the conditions or circumstances around their work environment (Ardika et al., 2015). 


\section{Analysis of Factors Affecting Employee Performance at Aetra Regional Drinking Water Company of Jakarta (PDAM) \\ Sari, Santoso, Permana, Wiwin., Sekarini}

$\mathrm{K} 3$ is a program created for workers and employers to prevent accidents and occupational diseases by recognizing things that have the potential to cause accidents and occupational diseases as well as anticipatory actions (Herlinawati \& Zulfikar, 2020). Work accidents cause production delays which can result in losses. Low or poor employee health will result in a tendency for high absenteeism and low productivity (Zahara, 2018).

Industrial accidents are generally caused by 2 (two) main things, namely dangerous work behavior (unsafe human act) and dangerous conditions (unsafe conditions). Several research results show that the human factor plays an important role in the incidence of work accidents. The results of the study stated that $80 \%-85 \%$ of work accidents are caused by negligence or human error ( Ahmad, 2013).

Therefore, the PT Aetra Air Jakarta agency is expected to have regulations on the occupational safety and health management system (SMK3) for employees so that K3. Companies should pay attention to the health of employees to provide healthier working conditions and become more responsible for these activities, especially for organizations that have a high accident rate (Rahman, 2020; Zahara, 2018).

Based on the results of the simultaneous test ( $F$ test), it is evident that work discipline and occupational safety and health have a positive and significant effect on employee performance with an F count 19,007 > F table 3,12, then Ho is accepted, meaning that work discipline and occupational safety and health are generally accepted. simultaneous effect on employee performance.

The magnitude of the close relationship between work discipline activities and occupational safety and health together with employee performance can be determined by the simultaneous determination coefficient factor (R2). In this multiple linear regression analysis obtained R2 of 0.339 or $(33.9 \%)$. This shows that the percentage of the contribution of the influence of the independent variable, namely work discipline and occupational safety and health on the employee performance variable is $33,9 \%$. Alternately, the independent variable used in the model can explain $33,9 \%$ of the variation in the dependent variable. While the remaining $66,1 \%$ is influenced by other variables that are not included in this research model.

Based on the hypothesis test, it is concluded that work discipline and occupational safety and health together have a positive relationship with employee performance. This positive relationship between work discipline and occupational safety and health on employee performance indicates that employee performance will increase if work discipline activities are good and occupational safety and health are created properly.

All relationships between variables show a positive sign, meaning that if there is an increase in the independent variables (Work Discipline (X1) and Occupational Safety and Health (X2), it will be followed by an increase in employee performance within PDAM Aetra Air Jakarta. All relationships fall into the strong category. These findings are following theory as evidenced by the following indicators: a). faithfulness; b). work performance; c). discipline; d). creativity; e). cooperation; f). skills and g). responsibility ( 


\section{CONCLUSION}

Based on the results of the analysis, it can be concluded that partially work discipline has a significant effect on performance. The higher the employee's work discipline, the positive and significant will increase the performance of employees in PT Aetra Air Jakarta. Partially, the Occupational Safety and Health (K3) variable also influences performance. The increase in Occupational Safety and Health (K3) will positively and significantly improve the performance of employees within PT Aetra Air Jakarta. After simultaneous regression testing, the two independent variables, namely work discipline and Occupational Safety and Health (K3) have a positive and significant effect on the performance of PT Aetra Air Jakarta employees. Of the two independent variables studied, the variable Occupational Safety and Health (K3) has the most influence on the performance of PT Aetra Air Jakarta employees.

Based on the results of the study, it was found that Work Discipline and Occupational Safety and Health (K3), both simultaneously and partially, had a significant effect on the performance of PT. AETRA AIR Jakarta. Based on the results of the research, the initial problem is that the discipline at PT Aetra Air Jakarta is still lacking. This can be seen from the value of testing the influence of discipline which is lower than the value of Occupational Safety and Health (K3). So, the managerial implication is that the company needs firmness, especially for employees whose absence rates are quite high. These problems have an impact on other employees so that it will affect the company's overall performance. This study shows that matters relating to discipline, and Occupational Safety and Health (K3) should be paid more attention and always improved to further spur employee performance in the PT Aetra Air Jakarta environment under the supervision of HRD.

\section{REFERENCE}

Adrizayani, S. (2014). Manajemen Sumber Daya Manusia (No. 1; Sistem Informasi Sumber Daya Manusia).

http://shafira_77.staff.gunadarma.ac.id/Downloads/files/24480/Manajemen+Sumber+D aya + Manusia.pdf

Adzim, H. I. (2021). Pengertian dan Definisi Keselamatan dan Kesehatan Kerja (K3). Sistem Manajemen Keselamatan Kerja.

https://sistemmanajemenkeselamatankerja.blogspot.com/2013/09/pengertian-dandefinisi-k3-keselamatan.html

Agha, S., Alrubaiee, L., \& Jamhour, M. (2011). Effect of Core Competence on Competitive Advantage and Organizational Performance. International Journal of Business and Management, 7(1). https://doi.org/10.5539/ijbm.v7n1p192

Ahmad, S. (2013). Paradigms of Quality of Work Life. Journal of Human Values, 19(1), 73-82. https://doi.org/10.1177/0971685812470345

Alfalla-Luque, R., Marin-Garcia, J. A., \& Medina-Lopez, C. (2015). An analysis of the direct and mediated effects of employee commitment and supply chain integration on organisational performance. International Journal of Production Economics, 162, 242-257. https://doi.org/10.1016/j.ijpe.2014.07.004 
Sari, Santoso, Permana, Wiwin., Sekarini

Ardika, G. K., Haris, I. A., \& Suwena, K. R. (2015). Pengaruh Pelaksanaan Keselamatan dan Kesehatan Kerja Terhadap Produktivitas Kerja di UD Sinar Abadi Singaraja. Jurnal Jurusan Pendidikan Ekonomi, 5(1), 1-11. https://doi.org/http://dx.doi.org/10.23887/jjpe.v5i1.6077

Arifudin, Sudirman, \& Andri, M. (2017). Evaluasi Sistem Manajemen Sumber Daya Manusia Pada Penempatan Kerja Petugas di UPT Puskesmas Lembasada. Jurnal Kesehatan Masyarakat Promotif, 7(1), 1-14. https://doi.org/10.31934/promotif.v7i1.20

Asadullah, M. A., Ul Haq, M. Z., Wahba, K., Hashmi, S., Kim, H. (Markham), \& Hwang, J. (2021). Gender differences and employee performance: Evidence from the restaurant industry. Journal of Hospitality and Tourism Management, 48, 248-255.

https://doi.org/10.1016/j.jhtm.2021.06.015

Avery, R. E., Smillie, L. D., \& Fife-Schaw, C. R. (2015). Employee achievement orientations and personality as predictors of job satisfaction facets. Personality and Individual Differences, 76, 5661. https://doi.org/10.1016/j.paid.2014.11.037

Bisht, N. S., \& Mahajan, A. (2021). Shared stressors and core self-evaluations: A trait activation perspective on employee performance. Journal of Business Research, 131, 103-111. https://doi.org/10.1016/j.jbusres.2021.03.053

Cai, M., Wang, W., Cui, Y., \& Stanley, H. E. (2018). Multiplex network analysis of employee performance and employee social relationships. Physica A: Statistical Mechanics and Its Applications, 490, 1-12. https://doi.org/10.1016/j.physa.2017.08.008

Carden, T., Goode, N., \& Salmon, P. M. (2021). Simplifying safety standards: Using work domain analysis to guide regulatory restructure. Safety Science, 138, 105096.

https://doi.org/10.1016/j.ssci.2020.105096

Creswell, J. W. (2017). Research Design Pendekatan Kualitatif, Kuantitatif, dan Mixed (S. Z. Qudsy (ed.); 3rd ed.). Pustaka Pelajar. https://opac.perpusnas.go.id/DetailOpac.aspx?id=1213690

Diana, R. (2015). Sumber Daya Manusia dan Produktivitas Kerja. Jurnal Istinbath, 15(1), 89-103. http://jurnal.radenfatah.ac.id/index.php/istinbath/article/view/779

Edison, E., Anwar, Y., \& Komariyah, I. (2017). Manajemen Sumber Daya Manusia. Bandung: Alfabeta. https://cvalfabeta.com/product/manajemen-sumber-daya-manusia/

Erpurini, W. (2019). Pengaruh Sistem Informasi Sumber Daya Manusia dan Disiplin Kerja Terhadap Kinerja Pada Karyawan CV. Cihanjuang Inti Teknik Cimahi. Jurnal Penelitian Ekonomi Dan Akuntansi JPENSI, 4(1), 1007. https://doi.org/10.30736/jpensi.v4i1.223

Fahmi, I. (2016). Manajemen Sumber Daya Manusia: Teori dan Aplikasi (M. Jalil (ed.); 1st ed.). Alfabeta. http://perpus.bandungkab.go.id/opac/detail-opac?id=6706

Ghozali, I. (2016). Aplikasi Analisis Multivariete dengan Program IBM SPSS 23 (I. Ghozali (ed.); 8th ed.). Badan Penerbit Universitas Diponegoro.

http://kin.perpusnas.go.id/DisplayData.aspx?pId=218217\&pRegionCode=UN11MAR\&p ClientId $=112$

Handoko, H. T. (2013). Manajemen Personalia dan Sumberdaya Manusia (6th ed.). BPFE. https://opac.perpusnas.go.id/DetailOpac.aspx?id=71648

Hardiyanti, R. (2017). Pengaruh Pembagian Kerja Dan Pengawasan Terhadap Efektivitas Kerja Pegawai di Kantor Kecamatan Sangatta Utara Kabupaten Kutai Timur. Jurnal Pemerintahan Integratif, 5(4), 570-580. 
Analysis of Factors Affecting Employee Performance at Aetra Regional Drinking Water Company of Jakarta (PDAM)

Sari, Santoso, Permana, Wiwin., Sekarini

https://jurnal.pancabudi.ac.id/index.php/jurnalfasosa/article/view/3476

Hasibuan, M. S. P. (2014). Manajemen Sumber Daya Manusia (12th ed.). Bumi Aksara. https:/ /opac.perpusnas.go.id/DetailOpac.aspx?id=576827

Herlinawati, H., \& Zulfikar, A. S. (2020). Analisis Penerapan Sistem Manajemen Keselamatan dan Kesehatan Kerja (SMK3). Jurnal Kesehatan, 8(1), 895-906. https://doi.org/10.38165/jk.v8i1.94

Irmawan, F. (2020). Human Capital Management, Manajemen Sumber Daya Manusia. https://pdfcoffee.com/human-capital-management-manajemen-sumber-daya-manusia-pdffree.html

Kazakovs, M., Verdina, A., \& Arhipova, I. (2015). Automation of Human Resources Development Planning. Procedia Computer Science, 77, 234-239. https://doi.org/10.1016/j.procs.2015.12.379

Khtatbeh, M. M., Mahomed, A. S. B., Rahman, S. bin A., \& Mohamed, R. (2020). The mediating role of procedural justice on the relationship between job analysis and employee performance in Jordan Industrial Estates. Heliyon, 6(10), e04973.

https://doi.org/10.1016/j.heliyon.2020.e04973

Kummetha, V. C., Kondyli, A., Chrysikou, E. G., \& Schrock, S. D. (2020). Safety analysis of work zone complexity with respect to driver characteristics - A simulator study employing performance and gaze measures. Accident Analysis \& Prevention, 142, 105566. https://doi.org/10.1016/j.aap.2020.105566

Lafuente, E., \& Abad, J. (2021). Territorial efficiency: Analysis of the role of public work safety controls. Safety Science, 134, 105074. https://doi.org/10.1016/j.ssci.2020.105074

Lan, J., Wong, C.-S., \& Zeng, G. (2021). Personality profiles for hospitality employees: Impact on job performance and satisfaction. International Journal of Hospitality Management, 98 , 103018. https://doi.org/10.1016/j.ijhm.2021.103018

Lussy, K. (2018). Pengaruh Penempatan dan Kompetensi Karyawan Terhadap Kinerja Karyawan Pada Perusahaan Daerah Panca Karya Ambon Bagian Transportasi Laut. Jurnal Manajemen Ekonomi Dan Akuntansi MANEKSI, 7(1), 26-38. https://doi.org/10.31959/jm.v7i1.88

Maden-Eyiusta, C., \& Alten, O. (2021). Expansion-oriented job crafting and employee performance: A self-empowerment perspective. European Management Journal. https://doi.org/10.1016/j.emj.2021.10.012

Mahawati, E., Fitriyatinur, Q., Yanti, C. A., Rahayu, P. P., Aprilliani, C., Chaerul, M., Hartini, E., Sar, M., Marzuki, I., Sitorus, E., Jamaludin, \& Susilawaty, A. (2021). Keselamatan Kerja dan Kesehatan Lingkungan Industri (1st ed.). Yayasan Kita Menulis. https:/ / kitamenulis.id/2021/01/26/keselamatan-kerja-dan-kesehatan-lingkungan-industri/

McLarty, B. D., Muldoon, J., Quade, M., \& King, R. A. (2021). Your boss is the problem and solution: How supervisor-induced hindrance stressors and LMX influence employee job neglect and subsequent performance. Journal of Business Research, 130, 308-317. https://doi.org/10.1016/j.jbusres.2021.03.032

Ningsih, S., Karyanto, B., Utami, F., Zahari, M., Sululing, S., Hatta, I. M., Setiawan, U., Putra, A. R., Marlena, N., Widodo, Z. D., Soedarto, W. S., \& Jumiati, E. (2021). Manajemen Sumber Daya Manusia (N. S. Wahyuni (ed.); 1st ed.). Widina Bhakti Persada. 
Analysis of Factors Affecting Employee Performance at Aetra Regional Drinking Water Company of Jakarta (PDAM)

Sari, Santoso, Permana, Wiwin., Sekarini

https://repository.penerbitwidina.com/media/publications/348968-manajemen-sumberdaya-manusia-06806f21.pdf

Ogunmokun, O. A., Eluwole, K. K., Avci, T., Lasisi, T. T., \& Ikhide, J. E. (2020). Propensity to trust and knowledge sharing behavior: An evaluation of importance-performance analysis among Nigerian restaurant employees. Tourism Management Perspectives, 33, 100590. https://doi.org/10.1016/j.tmp.2019.100590

Peong, H. K. (2019). The Effect of Corporate Social Responsibility and Talent Management on Employee Engagement (A Study at Tirta Komodo Regional Water Company, East Nusa Tenggara, Indonesia). KnE Social Sciences, 3(11), 967.

https://doi.org/10.18502/kss.v3i11.4064

Permana, E., Poerwoko, B., \& Widyastuti, S. (2019). Digital Capability and Innovation Strategy to Develop the Performance and Competitive Advantages of Fashion SMEs in Jakarta, Indonesia. International Journal of Managerial Studies and Research, 7(11), 5-15. https://doi.org/10.20431/2349-0349.0711002

Permana, E., Purwoko, B., Widyastuti, S., Widarto, R., \& Qosasi, A. (2020). Analisis Terhadap Diversitas Top Manajeman Tim (TMT) Pada BUMN Holding Di Indonesia. Jurnal Manajemen Dan Keuangan, 8(3), 336-353. https://doi.org/10.33059/jmk.v8i3.2091

Piwowar-Sulej, K. (2021). Human resources development as an element of sustainable HRM with the focus on production engineers. Journal of Cleaner Production, 278, 124008. https://doi.org/10.1016/j.jclepro.2020.124008

Pujangkoro, S. A. (2011). Analisis Jabatan (Job Analysis) [Universitas Sumatera Utara]. In e-USU Depository (Vol. 17, Issue 7). http:// repository.usu.ac.id/handle/123456789/1455

Purbaningrat, S. H. (2012). Komunikasi Transendental Dalam Bisnis Travel Haji dan Umrah di Indonesia. Sosiobumaniora, 14(2), 186. https://doi.org/10.24198/sosiohumaniora.v14i2.5489

Rahman, A. (2020). Urgensi Keselamatan dan Kesehatan Kerja dan Lingkungan (K3L). Jurnal Keselamatan Kesehatan Kerja Dan Lingkungan, 1(1), 1-2. https://doi.org/10.25077/jk31.1.1.12.2020

Rustandi, R. (2019). Kinerja Manajemen Sumber Daya Manusia di Era Disrupsi. Kebijakan: Jurnal Ilmu Administrasi, 10(2), 67. https://doi.org/10.23969/kebijakan.v10i2.1653

Sugiyono. (2019). Metode Penelitian Kuantitatif Kualitatif dan R\&D (I). Alfabeta. https://cvalfabeta.com/product/metode-penelitian-kuantitatif-kualitatif-dan-rd-mpkk/

Sujatha, R., \& Krishnaveni, R. (2018). Knowledge creating ba as a determinant of work performance of employees: An empirical analysis among pump manufacturing firms in South India. Asia Pacific Management Review, 23(1), 45-52. https://doi.org/10.1016/j.apmrv.2017.01.006

Tordera, N., Peiró, J. M., Ayala, Y., Villajos, E., \& Truxillo, D. (2020). The lagged influence of organizations' human resources practices on employees' career sustainability: The moderating role of age. Journal of Vocational Behavior, 120, 103444. https://doi.org/10.1016/j.jvb.2020.103444

Utamy, R., Ahmad, S., \& Eddy, S. (2020). Implementasi Manajemen Sumber Daya Manusia. Journal of Education Research, 1(3), 225-236. https://doi.org/10.37985/jer.v1i3.26

Wangi, V. K. N. (2020). Dampak Kesehatan Dan Keselamatan Kerja, Beban Kerja, Dan 
Analysis of Factors Affecting Employee Performance at Aetra Regional Drinking Water Company of Jakarta (PDAM)

Sari, Santoso, Permana, Wiwin., Sekarini

Lingkungan Kerja Fisik Terhadap Kinerja. Jurnal Manajemen Bisnis, 7(1), 40-50. https://doi.org/10.33096/jmb.v7i1.407

Wicaksono, Y. S. (2016). Pengaruh Pelatihan dan Pengembangan Sumber Daya Manusia dalam Rangka Meningkatkan Semangat Kerja dan Kinerja Karyawan (Studi di SKM Unit V PT.

Gudang Garam,Tbk Kediri). Jurnal Bisnis Dan Manajemen, 3(1), 31-39.

https://doi.org/https://doi.org/10.26905/jbm.v3i1.71

Zahara, S. (2018). Hubungan Pengetabuan Keselamatan dan Kesehatan Kerja (K3) Dengan Kecelakaan Kerja Pada Tukang Las di Kecamatan Medan Kota [Universitas Sumatera Utara]. https://repositori.usu.ac.id/handle/123456789/7346

Zhang, L. (2018). Hypothetical Analysis of Employees' Work Performance based on HPHRP. Procedia Engineering, 211, 1128-1130. https://doi.org/10.1016/j.proeng.2017.12.119

Zhou, D. (2021). Role of green data center in human resources development model. Sustainable Computing: Informatics and Systems, 30, 100492. https://doi.org/10.1016/j.suscom.2020.100492 